\title{
Pelatihan Manajemen Kas Rumah Tangga Untuk Mencegah Kegagalan Keuangan Rumah Tangga (Family Financial Distress)
}

\author{
Houssehold Cash Management Training to \\ Prevent Family Financial Failure (Family Financial Distress)
}

\author{
Ida Subaida \\ Email: idaa.subaida@gmail.com \\ Universitas Abdurachman Saleh Situbondo
}

\begin{abstract}
Abstrak : Tujuan dan target yang ingin dicapai dalam kegiatan pengabdian kepada masyarakat ini adalah pelaksanaan pelatihan teknis manajemen kas rumah tangga sehingga dapat mencegah kegagalan keuangan rumah tangga. Luaran yang dihasilkan adalah metode manajemen kas rumah tangga, menumbuhkan rumah tangga yang memiliki manajemen kas yang baik, meningkatkan pengetahuan pentingnya pengaturan keuangan rumah tangga menjadi produktif, menumbuhkan pemahaman untuk dapat secara bertahap dapat terhindar dari ketergantungan lembaga-lembaga peminjaman, dan meningkatkan kesejahteraan rumah tangga.

Kata Kunci: Manajemen Keuangan, Manajemen Kas Rumah Tangga, Family Financial Distress

Abstract : The aim and target to be achieved in this community service activity is the implementation of family cash management technical training so that it can prevent family financial distress. The output generated is the method of family cash management, growing family that have good cash management, increasing knowledge of the importance of regulating family finances to be productive, fostering understanding to be able to gradually avoid dependence on lending institutions, and improving familywelfare.
\end{abstract}

Keyword: Financial Management, Family Cash Management, Family Financial Distress

\section{PENDAHULUAN}

Manajemen Keuangan adalah serangkaian kegiatan yang mencakup kegiatan pencarian dana dan pengelolaan dana yang diperoleh dengan beberapa tujuan yang menyeluruh yang ingin dicapai. Oleh karena itu kebijakan berkaitan dengan manajemen keuangan mencakup keputusan investasi, keputusan pendanaan, dan manajemen aset (Takdir, 2008). Menurut Sugiyarso dan Winarni (2005) Kegiatan manajemen keuangan tidak terbatas dilakukan oleh Manajer 


\section{INTEGRITAS : JurnalPengabdian}

Vol 3, No 1, Juli 2019

ISSN 2580-7978 (Cetak) ISSN 2615-0794 (Online)

Keuangan dalam sebuah perusahaan, dalam kehidupan sehari-hari setiap orang akan berhubungan dengan kegiatan keuangan tersebut. Suhartini dan Ardhian (2007) mengemukakan bahwa tidak hanya perusahaan yang perlu mengelola keuangannya secara baik, keluarga dan individu juga harus mampu menangani keuangannya dengan baik.

Perkembangan manajemen keuangan juga diikuti oleh perkembangan ilmu akuntansi. Saat ini ilmu akuntansi mengalami perkembangan yang sangat pesat, yaitu akuntansi tidak hanya mencakup tentang transaksi pada perusahaan saja. Akuntansi juga dibutuhkan oleh industri kecil, industri rumahan bahkan pada organisasi terkecil yaitu rumah tangga. Menurut Megawangi (2003) keluarga penting dalam rangka membentuk karakter suatu bangsa. Jika keluarga yang merupakan suatu fondasi masyarakat lemah, maka masyarakat pun akan lemah. Oleh karena itu diyakini bahwa berbagai masalah masyarakat seperti krisis moal, kejahatan seksual, dan kekerasan di masyarakat merupakan akibat dari lemahnya pengawasan institusi dalam lingkungan keluarga.

Keuangan rumah tangga berkaitan dengan bagaimana rumah tangga melakukan investasi kemudian menggunakannya untuk mencapai tujuan. Rumah tangga memiliki persoalan dengan ciri khusus yang mencerminkan karakternya sendiri (Pangeran,2012). Menurut Garlans (2014) Perencanaan keuangan adalah hal yang wajib dilakukan bagi siapa saja yang menginginkan keberhasilan keuangan yaitu jumlah kekayaan lebih besar dari liabilitasnya. Orang yang berhasil dalam keuangan tesebut mampu menyelaraskan antara penggunaan dana dengan pendapatan yang diperoleh.

Pemberian pemahaman mengenai keuangan masyarakat sangat diperlukan. Pembangunan dan pertumbuhan ekonomi yang pesat mengakibatkan lembaga keuangan mempunyai peran yang penting dalam kehidupan masyarakat secara luas. Masyakat juga perlu memahami dengan benar manfaat dan risiko agar masyarakat dapat mengetahui hak dan kewajiban serta meyakini bahwa produk dan layanan jasa keuangan yang dipilih dapat meningkatkan kesejahteraan 


\section{INTEGRITAS : JurnalPengabdian}

Vol 3, No 1, Juli 2019

ISSN 2580-7978 (Cetak) ISSN 2615-0794 (Online)

masyarakat (Novi, 2017). Pemberian pemahaman tersebut juga untuk memberikan pemahaman mengenai pemakaian atau pemanfaatan sumber keuangan yang dimiliki.

Seseorang perlu belajar manajemen yang lebih tepat dan bijaksana karena terdapat beberapa keluarga yang tidak mampu mengelola keuangannya tersendiri. Rumah tangga yang tidak mampu mengelola keuangannya tersebut akan berdampak pada kehancuran dari segi keuangan dan mendorong untuk melakukan peminjaman keuangan secara terus menerus kepada bank, koperasi, bahkan debtcollector. Kesulitan keuangan juga dapat mengakibatkan terjadinya kehilangan teman bahkan terjadinya perceraian dalam rumah tangga.

Oleh karena itu diperlukan pelaksanaan pelatihan Manajemen Kas Rumah bagi ibu Rumah Tangga di Dusun patrol RT 1 RW 5. Ibu rumah tangga dipilih sebagai peseta pelatihan karena menurut Rahmah (2014) ibu rumah tangga memiliki peranan yang sangat penting dalam pembentukan keluarga sejahtera sebagai bagian terkecil dalam masyarakat.

Dusun patrol RT 1 RW 5 merupakan sebuah dusun yang terletak di desa Tokelan Kecamatan Panji Kabupaten Situbondo. Jarak wilayah tersebut dengan pusat kota Situbondo berjarak 3,9 KM. Jarak tersebut cukup dekat sehingga akses terhadap fasilitas -fasilitas umum seperti kesehatan, pendidikan, keagamaan, dan hiburan masih tergolong mudah. Berdasarkan survey awal yang dilakukan, terdapat 29 Rumah Tangga di dusun tersebut.

Mata pencaharian masyarakat dusun patrol RT 1 RW 5 mayoritas adalah sebagai petani dan buruh tani. Mata pencaharian tersebut mengakibatkan penerimaan keuangan oleh masyarakat terpusat saat musim panen tiba. Hal tersebut menyebabkan kondisi keuangan masyarakat pada saat bukan musim panen menjadi terbatas.

Kasus yang penah terjadi di dusun patrol RT 1 RW 5 adalah dilakukannya penyitaan barang-barang berharga seperti televisi, kulkas, sepeda motor, kursi dan meja tamu oleh lembaga-lembaga peminjaman uang seperti bank, koperasi, 


\section{INTEGRITAS : JurnalPengabdian}

Vol 3, No 1, Juli 2019

ISSN 2580-7978 (Cetak) ISSN 2615-0794 (Online)

bahkan debtcollector. Penyitaan tersebut dikarenakan masyarakat yang bersangkutan tidak dapat melunasi utangnya dalam jangka waktu yang telah disepakati sebelumnya.

Permasalahan lain terkait keuangan rumah tangga yang terjadi di dusun Patrol adalah masih redahnya tingkat pendidikan masyarakat. Berdasarkan survey awal yang dilakukan dari 29 Rumah Tangga, hanya 2 orang yang telah lulus strata satu dan terdapat 4 orang sedang menempuh strata satu. Sedangkan sebagian besar masyarakat hanya menempuh pendidikan sampai jenjang SMA, SMP, SD, bahkan tidak lulus SD. Salah satu penyebab rendahnya tingkat pendidikan tersebut karena keterbatasan keuangan. Menurut Teguh et al (2015) Keterbatasan ekonomi dan keluarga sering menjadi penyebab pertengkaran diantara suami dan istri sehingga membuat keluarga tersebut tertekan dalam menyikapi keuangan.

\section{METODE PELAKSANAAN}

Metode pelaksanaan kegiatan pelatihan Manajemen Kas Rumah Tangga Untuk Mencegah Kegagalan Keuangan Rumah Tangga (Family Financial Distress) digambarkan dalam gambar 1. Berupa solusi yang ditawarkan untuk mengatasi permasalahan yang ada.

Masyarakat dusun patrol RT 1 RW 5 desa Tokelan kecamatan Panji yang akan diwakili oleh ibu rumah tangga akan diberikan pemahaman mengenai gambaran umum pentingnya manajemen kas rumah tangga, bagaimana cara melaksanakan manajemen rumah tangga dengan metode yang sederhara, mudah dipahami, dan mudah diterapkan, pemberian beberapa contoh kasus manajemen kas, dan diskusi mengenai permasalahan yang pernah dihadapi peserta terkait kas rumah tangga.

Hasil pelatihan akan diberikan pendampingan dan evaluasi untuk mendukung pelaksanaan manajemen kas rumah tangga. Observasi tersebut dilakukan 2 minggu setelah pelaksanaan pelatihan. Rumah tangga juga diharapkan 
dapat secara berkelanjutan menerapkanmanajemen kas yang baik dalam kegiatan rumah tangga setelah kegiatan PKM telah selesai.

\begin{tabular}{|l|l|}
\hline \multicolumn{2}{|c|}{ PERMASALAHAN MITRA } \\
\hline & $\begin{array}{l}\text { Minimnya pengetahuanmanajemen kas } \\
\text { dalam rumah tangga }\end{array}$ \\
\hline
\end{tabular}

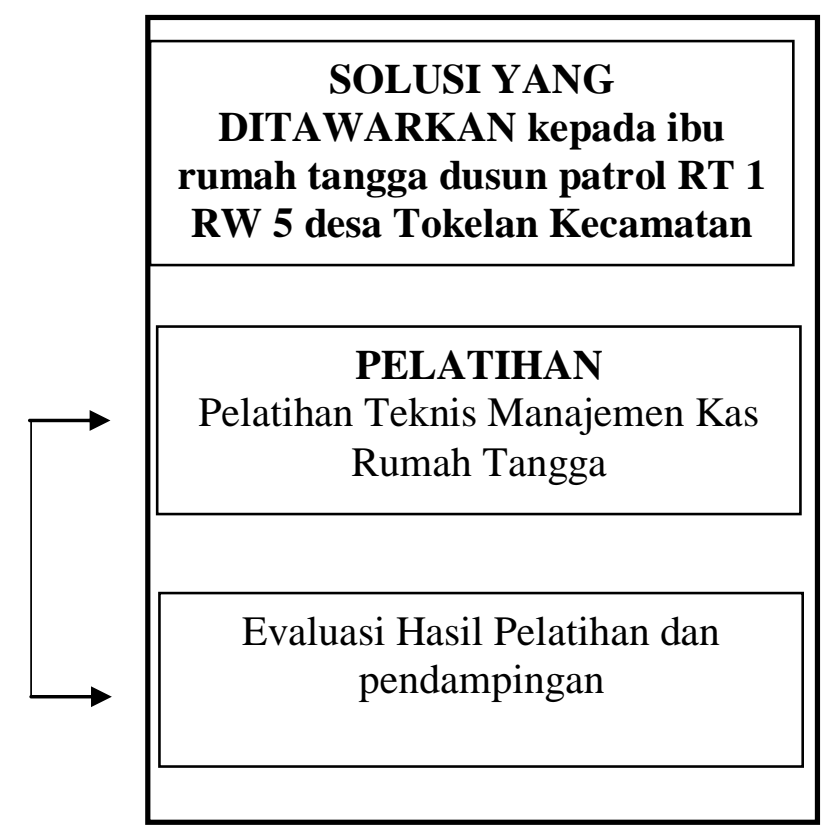

Gambar 1. Permasalahan dan solusi kepada Mitra

\section{HASILDAN LUARAN YANG DICAPAI}

\section{Hasil Kegiatan}

Pelatihan manajemen kas rumah tangga bagi ibu rumah tangga di dusun Patrol RT 1 RW 5 desa Tokelan kecamatan Panji Kabupaten Situbondo diselenggararakan di salah satu rumah warga di dusun Patrol RT 1 RW 5 desa Tokelan kecamatan Panji Kabupaten Situbondo yaitu rumah ibu Siti pada hari Selasa tanggal 09 April 2019 pukul 15.00 WIB. Pelatihan dihadiri oleh 8 ibu rumah tangga di dusun Patrol RT 1 RW 5 desa Tokelan kecamatan Panji Kabupaten Situbondo.

Pelatihan tersebut diberikan untuk memberikan pemahaman kepada ibu rumah tangga mengenai manajemen kas rumah tangga. Pentingnya manajemen penerimaan penghasilan keluarga dan manajemen pengeluaran untuk kebutuhan 


\section{INTEGRITAS : JurnalPengabdian}

Vol 3, No 1, Juli 2019

ISSN 2580-7978 (Cetak) ISSN 2615-0794 (Online)

rumah tangga sehari-hari dan kebutuhan rutin lainnya seperti pendidikan dan kesehatan. Dalam pelatihan teknis yang dilakukan, peserta diberikan gambaran umum mengenai pentingnya manajemen kas rumah tangga, bagaimana cara melaksanakan manajemen rumah tangga dengan metode yang sederhana, mudah dipahami, dan mudah diterapkan, pemberian beberapa contoh kasus manajemen kas, dan diskusi mengenai permasalahan yang pernah dihadapi peserta terkait kas rumah tangga.

Gambaran umum mengenai pentingnya manajemen kas rumah tangga diberikan dalam bentuk pemaparan kondisi keuangan keluarga yang sering kali terjadi di dusun Patrol desa Tokelan yaitu rumah tangga kurang dapat memanajemen penerimaan dan pengeluaran keuangannya. Penghasilan masyarakat terpusat pada saat musim panen, yang mengakibatkan pengeluaran yang dikeluarkan pada saat tersebut juga berbanding lurus yaitu mengalami peningkatan dan dibeberapa kondisi pengeluaran tersebut bukan pada pengeluaran yang bersifat pokok. Kondisi tersebut mengakibatkan pada saat bukan musim panen, penghasilan yang diterima tidak dapat membiayai semua pengeluaran pokok yang dibutuhkan, seperti kesehatan dan pendidikan. Rumah tangga akan memutuskan untuk melakukan pinjaman kepada lembaga-lembaga peminjaman untuk memenuhi kebutuhan rumah tangga tersebut.

Jika kondisi tersebut terus berlanjut tanpa ada adanya kesadaran pemahaman akan pentingnya mengelola kas rumah tangga dengan baik dan upaya perbaikan yang dilakukan, siklus ekonomi semacam itu akan terus berlanjut. Bahkan pada saat musim panen, penghasilan tersebut digunakan untuk melunasi pinjaman pada periode panen sebelumnya.

Kondisi yang bahkan terjadi adalah penyitaan barang-barang rumah tangga seperti televisi, kursi, dan barang lainnnya sebagai akibat jika rumah tangga tidak dapat melunasi pinjamannya kepada lembaga-lembaga peminjaman. Dampak lainnya juga dana untuk pendidikan dan kesehatan kadang tidak menjadi prioritas. Dengan pemberian pemahaman pentingnya manajemen kas rumah tangga 


\section{INTEGRITAS : JurnalPengabdian}

Vol 3, No 1, Juli 2019

ISSN 2580-7978 (Cetak) ISSN 2615-0794 (Online)

tersebut, diharapkan peserta dapat meningkatkan pemahahaman dan menumbuhkan niat untuk berupaya lebih baik lagi dalam mengelola keuangan rumah tangga.

Setelah diberikan pemahaman akan pentingnya manajaemen rumah tangga, peserta diberikan pelatihan mengenai bagaimana metode manajemen kas yang dapat diterapkan dalam rumah tangga. Peserta diberikan pelatihan untuk mengadministrasikan dengan baik penghasilan yang diperoleh dan perikiraan rincian jumlah pengeluaran yang dibutuhkan. Dengan dicatat dengan lengkap dan tertib penerimaan dan pengeluaran, rumah tangga dapat memilih skala prioritas pengeluaran yang diperbolehkan untuk dikeluarkan dengan menyesuaikan penghasilan yang diterima selama periode tertentu, misal dari musim panen saat ini sampai musim panen berikutnya. Metode tersebut diharapkan dapat mengendalikan pengeluaran yang tidak terlalu dibutuhkan dalam keluarga untuk ditiadakan atau ditunda di waktu yang akan datang dengan menyesuaiakan penghasilan yang diterima.

Kegiatan tersebut merupakan kegiatan perencanaan keuangan yang memang dibutuhkan oleh keluarga. Menurut Yonshon (2004), perencanaan keuangan menjadi proses awal dalam pelaksanaan manajemen keuangan. Namun tidak banyak keluarga yang telah membuat perencanaan keuangannya dengan baik. Keluarga beranggapan tidak diperlukan pembuatan perencanaan keuangan karena diasumsikan pendapatan dan pengeluaran setiap bulan tidak menentu.

Dalam metode administrasi penerimaan penghasilan dan pengeluaran tersebut juga perlu dianggarkan sebagian untuk tabungan atau cadangan keuangan untuk tabungan dimasa depan atau untuk membiaya pengeluaran tidak terduga. Harapannya adalah untuk meminimalkan bahkan meniadakan peminjaman uang kepada lembaga-lembaga keuangan yang ada. Bunga atau jasa yang seharusnya dibayarkan atas pinjaman tersebut, dapat dialokasikan untuk kebutuhan rumah tangga lainnya atau untuk tambahan tabungan rumah tangga yang bersangkutan. 


\section{INTEGRITAS : JurnalPengabdian}

Vol 3, No 1, Juli 2019

ISSN 2580-7978 (Cetak) ISSN 2615-0794 (Online)

Sesi terakhir pelatihan teknis manajemen kas rumah tangga yaitu diberikan alokasi waktu untuk sharing dan diskusi terkait kondisi keuangan rumah tangga dan kendala yang sering dialami oleh peserta. Permasalahan dan kondisi ekonomi masing-masing keluarga berbeda, sehingga perlu ditelaah dan ditindaklanjuti manajemen keuangannya dengan penyesuaian dari kondisi keuangan masingmasing.

Dua minggu setelah pelatihan teknis manajemen kas rumah tangga dilakukan yaitu tepatnya mulai tanggal 22 April 2019, dilakukan evaluasi hasil pelatihan dan pendampingan bagi peserta pelatihan yang dilakukan secara bergantian di rumah masing-masing peserta. Kegiatan ini berupa kegiatan diskusi mengenai apakah sudah mulai melaksanakan pencatatan penerimaan dan pengeluaran dalam rumah tangga, kendala yang dihadapi, dan pemberian masukan-masukan agar hasil penelitian yang telah dilakukan dapat bermanfaat bagi peserta pelatihan dan keluarganya.

\section{Luaran Yang Dicapai}

Luaran yang telah dicapai atas Program Kemitraan Masyarakat (PKM) ini yaitu metode manajemen kas rumah tangga, menumbuhkan rumah tangga yang memiliki manajemen kas yang baik, meningkatkan pengetahuan pentingnya pengaturan keuangan rumah tangga menjadi produktif, menumbuhkan pemahaman untuk dapat secara bertahap dapat terhindar dari ketergantungan lembaga-lembaga peminjaman, meningkatkan kesejahteraan rumah tangga di dusun Patrol RT 1 RW 5 desa Tokelan Kecamatan Panji.

\section{KESIMPULAN DAN SARAN}

Kegiatan ini merupakan pelatihan teknis manajemen kas rumah tangga. Minimnya pemahaman mengenai manajemen kas rumah tangga sehingga dapat menyebabkan kegagalan keuangan rumah tangga (family financial distress). Persoalan tersebut dapat menyebabkan persoalan-persoalan lainnya yakni, ketergantungan masyarakat terhadap lembaga-lembaga peminjaman uang seperti 


\section{INTEGRITAS : JurnalPengabdian}

Vol 3, No 1, Juli 2019

ISSN 2580-7978 (Cetak) ISSN 2615-0794 (Online)

bank, koperasi, bahkan debtcollector, rendahnya tingkat pendidikan khususnya setiap anak dalam rumah tangga, serta kualitas kesehatan yang sesuai kondisi keuangan masyarakat yang terbatas.

Pelatihan teknis ini dikukan dengan pemberian gambaran umum mengenai pentingnya manajemen kas rumah tangga, bagaimana cara melaksanakan manajemen rumah tangga dengan metode yang sederhara, mudah dipahami, dan mudah diterapkan, pemberian beberapa contoh kasus manajemen kas, dan diskusi mengenai permasalahan yang pernah dihadapi peserta terkait kas rumah tangga. Luaran yang dihasilkan adalah metode manajemen kas rumah tangga, menumbuhkanrumah tangga yang memiliki manajemen kas yang baik, meningkatkan pengetahuan pentingnya pengaturan keuangan rumah tangga menjadi produktif, menumbuhkan pemahaman untuk dapat secara bertahap dapat terhindar dari ketergantungan lembaga-lembaga peminjaman, dan meningkatkan kesejahteraan rumah tangga di dusun Patrol RT 1 RW 5 desa Tokelan Kecamatan Panji.

Saran yang bisa diberikan atas pelaksanaan Program Kemitraan Masyarakat (PKM) kepada kedua mitra yaitu dibutuhkannya pemahaman dan kesadaran dari rumah tangga akan pentingnya manajemen kas rumah tangg untuk mencegah kegagalan keuangan rumah tangga. Rumah tangga juga perlu menerapkan metode manajemen kas rumah tangga yang telah diberikan dalam kegiatan pelatihan dalam pengelolaan keuangan rumah tangga sehari secara tertib, konsisten, dan berkelanjutan.

\section{DAFTAR PUSTAKA}

Garlans, S.N. 2014. Motivasi Sebagai Penentu Perencanaan Keuangan. Jurnal Ilmiah Akuntansi dan Bisnis, Vol. 9, No.1:42-48.

Megawati, Ratna. 2003. Pendidikan Karakter untuk Membangun Masyarakat Madani. IPPK Indonesia Heritage Foundation. 
Novi, Y.A. 2017. Pentingnya Literasi Keuangan bagi Pengelolaan Keuangan Pribadi. 2017. Jurnal Nominal, Vol.6., No. 1:11-26.

Pangeran, Perminas. 2012. Sikap Keuangan Rumah Tangga Desa pada Aspek Perencanaan Keuangan. JRAK, Vol.8, No.1:35-50.

Rahmah, Sitti. 2014. Pola Pengelolaa Keuangan Keluarga pada Ibu Rumah Tangga (Studi pada Ibu Rumah Tangga yang Bekerja Sebagai Cleaning Service di UIN Sultan Syarif Kasim Riau). Marwah, Vol. 8, No.1:132-152.

Sugiyarso, G. Dan Winarni, F. 2005. Manajemen Keuangan. Yogyakarta: Media Pressindo.

Suhartini, Dwi dan Ardhian, R.J. 2007. Pengelolaan Keuangan Keluarga Pedagang Etnis Cina. Jurnal Riset Ekonomi dan Bisnis, Vol. 7, No.2:70-81.

Takdir, Dedy S. 2008. Manajemen Keuangan (Tteori dan Aplikasi).Kendari: Unhalu Press.

Teguh, R.I, Puspitawati, Herien, dan Krisnatuti, Diah. 2015. Tatanan Ekonomi, Manajemen Keuangan, dan Kesejahteraan pada Keluarga Muda. Julnal Ilmiah Keluarga \& Konseling, Vol. 8, No. 1: 38-48.

Yonshon. 2004. Peran Universitas di Surabaya dalam Meningkatkan Jumlah Kleuarga Mapan di Surabaya (Seri Penelitian Keuangan Keluarga). Jurnal Manajemen \& Kewirausahaan,Vol. 6, No. 1:54-71. 